\title{
The Corrosion Resistance of Turbocharger Stator after Plasma Nitriding Process
}

Ondrej Pilch ${ }^{1}$,Petr Faltejsek ${ }^{1}$, Vojtěch Hrubý ${ }^{1}$, Michal Krbat’a ${ }^{2}$

${ }^{1}$ University of Defence, Faculty of Military Technology, Department of Mechanical Engineering, Kounicova 65, 662 10 Brno, Czech Republic,

${ }^{2}$ Alexander Dubcek University of Trencin, Faculty of Special Technology, Pri parku 19, 91106 Trenčín, Slovak Republic,

The plasma nitriding technology was applied on the turbocharger stator wheel. Martensitic stainless steel X12Cr13 was choosen for the experiment. The influence of plasma nitriding process on the corrosion resistance of selected steel was investigated. The chemical composition of selected steel was verified using the Q4 TASMAN device. After plasma cleaning procedure was plasma nitriding process performed using two stage nitriding procedure. The microstructure and mechanical properties of the nitride layers were studied using optical and laser confocal microscopy and hardness testing. The depths of plasma nitride layers were also estimated using cross-sectional microhardness profiles measuring. The corrosion resistance of plasma nitrided X12Cr13 steel samples were evaluated in a $5 \%$ neutral sodium chloride solution (NSS) in accordance with ISO 9227 standard in the VLM GmbH SAL 400-FL corrosion chamber and visually verified. Microhardness and surface hardness of experimental samples were significantly increased, but the corrosion resistance significantly decreased.

Keywords: plasma nitriding, stainless steel, nitride layer, corrosion resistance

\section{Acknowledgements}

The paper has been prepared thanks to the support of the project "The Development of Technologies, Design of Firearms, Ammunition, Instrumentation, Engineering of Materials and Military Infrastructure VÝZBROJ (DZRO K201)." and "Surface technology in applications special techniques SV16-216."

\section{References}

[1] POKORNÝ, Z., STUDENÝ, Z., HRUBÝ, V. (2016). Effect of nitrogen on surface morphology of layers. Metallic materials, Vol. 54, No. 2, pp. 119-124. ISSN 1338-4252.

[2] STUDENÝ, Z. (2015). Analysis of the influence of initiating inclusions on fatigue life in plasma nitrided steels. Manufacturing Technology, Vol. 15, No. 1, pp. 99-105. ISSN 1213-2489.

[3] PYE, D. (2003). Practical nitriding and ferritic nitrocarburizing. Materials Park, Ohio: ASM International.

[4] ROTNIK, U., DOLECEK, V., VEHOVAR, L., BOZIC, S. (2006). The corrosion resistance of nitrogen-alloyed austenitic stainless steel to pitting processes under conditions of erosion corrosion. Mettalic materials, Vol. 44, No. 2, pp. 89 - 99. ISSN 0023-432X.

[5] KUSMIC, D., DOBROCKY, D. (2015) Corrosion Resistance of Plasma Nitrided Structural Steels. Manufacturing Technology, Vol. 15, No. 1, pp. 64-69. ISSN 1213-2489.

[6] POKORNÝ, Z., KADLEC, J., HRUBÝ, V., et all. (2011). Hardness of plasma nitrided layers created at different conditions. Chemické listy, Vol. 2011, No. 105, pp. 717-720. ISSN 1213-7103.

[7] PAYLING, R., JONES, D., BENGTSON, A. (1997). Glow Discharge Optical Emission Sepctometry. England: John Wiley \& Sons Ltd. ISBN 0-471-96683-5.

[8] KADLEC, J. (2008). Metodika hodnocení chemickeho složení a vlastností povlaků FeFe2O4, 18s. Univerzita obrany, Brno ISBN: 978-7231-474-4.

[9] EN ISO 6507-1 Metallic materials - Vickers hardness test - Part 1: Test method. 1998

[10] STN EN ISO 14577-1: Metallic materials Instrumented indentation test for hardness and materials parameters Part 1: Test method.

[11] KUSMIČ, D., DOAN, T., V., PILCH, O., KRBAŤA, M. (2017). Corrosion resistance and tribological properties of plasma nitrided and tenifered $42 \mathrm{crmo} 4$ steel. In: 25th Anniversary International Conference on Metallurgy and Materials (METAL). Ostrava: TANGER Ltd., Ostrava. pp. 1103-1108. ISBN 978-80-87294-67-3.

[12] DONG-CHERNG W. (2009). Microstructure and corrosion resistance of the layer formed on the surface of precipitation hardenable plastic steel by plasma-nitriding, Applied Surface Science, Vol. 256, pp. 797-804. ISSN 01694332. 
[13] BASU A., DUTTA MAJUMDAR J., et al. (2008). Corrosion resistance improvement of high carbon low alloy steel by plasma nitriding, Materials Letters, Vol. 62, pp. 3117-3120. ISSN 0167-577X.

[14] KUSMIČ, D., HRUBÝ, V., BACHÁROVÁ, L. (2017). Corrosion resistance of surface treated $42 \mathrm{CrMo} 4$ steel. Mettalic materials, Vol. 54, No. 6, pp. 491-496. ISSN 0023-432X.

[15] DIN 50190-4:1999, Hardness depth of heat-treated parts - Part 4: Determination of the diffusion hardening depth and the diffusion depth.

[16] HRUBÝ, V., POKORNÝ, Z., BARBORÁK, O. (2012). Characteristics of plasma nitrided layers in deep holes. Metallic materials, Vol. 3, No. 50, pp. 209-212. ISSN 0023-432X.

[17] POKORNÝ, Z., STUDENÝ, Z., POSPÍCHAL, M., HRUBÝ, V., JOSKA, Z. (2015). Characteristics of plasma nitrided layers. Manufacturing Technology, Vol. 15, No. 3, pp. 403-409. ISSN 1213-2489.

Copyright $(\mathbb{2}$ 2017. Published by Manufacturing Technology. All rights reserved. 